\section{Copyright-ERIC database}

In a November 3, 1992, letter, the Department of Education (ED) solicited comments from users concerning proposed changes to ERIC. Robert Stonehill, director of the Educational Resources Information Center (ERIC), announced that in November 1991 ED modified the contract for the ERIC Processing and Reference Facility, which produces the ERIC database tapes, permitting the contractor "to copyright the ERIC database and to collect modest feessubject to ED approval-for commercial and academic usage."

The House of Representatives in September 1992 passed H.R. 4014, an educational research bill which included a prohibition against copyright of the ERIC database and the charging of royalties and user fees, but the Senate did not take up the bill. In November House Education and Labor Committee Chairman William Ford (D-Mich.) wrote to Secretary of Education Lamar Alexander: "I believe the public interest is best served if databases such as the ERIC database are in the public domain, and that federal agencies should avoid permitting contractors to establish exclusive, restricted, or other distribution arrangements."

ERIC officials were expected to be presenting their views to various groups at the AlA Midwinter Meeting in Denver. In July 1992 the ALA Council passed a resolution opposing contractor copyright and use royalties for the ERIC database. Congressional opponents of ERIC database copyright are expected to take up the issue again this year.

\section{NREN-OSTP report to Congress}

President Bush's science advisor issued a report December 8 on six NREN policy issues on which Congress had requested advice. Rather than making any major policy recommendations, the document is more of a status report. The major weakness of the report is that it views the very broad current and near-term future use of the Internet and evolving National Research and Education Network as pressure from nonfederal constituency groups whose partici- pation may not be appropriate for the NREN.

This narrow view sees little role for government in stimulating and taking advantage of the enormous potential the high-capacity NREN holds for transforming education and research. Such a narrow view is at odds with the provisions of the High Performance Computing Act itself, which calls for federal agencies to work with libraries, among others, to ensure that researchers, educators, and students have access to libraries, electronic information resources, and government information.

"The National Research and Education Network Program; A Report to Congress" from D. Allan Bromley, director of the Office of Science and Technology Policy (OSTP), is available from the National Coordination Office for High Performance Computing and Communications, 8600 Rockville Pike, Bldg. 38-A, Room B1N30, Bethesda, MD 20894; (301) 402-4100.

ALA and ACRL participated in two cooperative efforts to provide input on the OSTP report; both are minimally quoted and cited by OSTP. Proceedings of the NREN Workshop summarize a September 1992 policy workshop sponsored by the Institute for Electrical Engineering and Electronics, EDUCOM, and the Computing Research Association (see this column in last month's issue). "Report to the Office of Science and Technology Policy on Library and Information Services' Roles in the National Research and Education Network" summarizes the July 1992 forum held by the U.S. National Commission on Libraries and Information Science. Both these activities were important in providing mechanisms for NREN constituencies to develop their opinions. The NCLIS report is available from the U.S. National Commission on Libraries and Information Science, 1111 18th St. NW, Suite 310, Washington, DC 20036; (202) 254-3100.

Carol $C$. Henderson is deputy executive director of ALA's Washington Office; bitnet: $N U \_A L A W A S H$ QCUA 